\title{
In vivo ultrathin Descemet stripping automated endothelial keratoplasty with a low-energy and high-frequency femtosecond laser
}

\author{
In vivo Descemet stripping automated endothelial keratoplasty ultrafina com laser de femtosegundo \\ de baixa energia e alta frequência
}

Gustavo Victor ${ }^{1}$, Walton Nosé2 ${ }^{2}$, Sidney Júlio de Faria e Sousa ${ }^{3}$, Adriana dos Santos Forseto², Milton Ruiz Alves ${ }^{1}$

\begin{abstract}
This case report describes the production of an ultrathin endothelial donor corneal lamella using a femtosecond laser with low energy and a high frequency. In addition, we report its use in vivo in an eye with pseudophakic bullous keratopathy. The outcomes were observed 3 months after surgery in terms of the change in endothelial donor lamella and full cornea thickness (including pachymetric mapping), visual acuity, and endothelial cell count.
\end{abstract}

Keywords: Descemet stripping endothelial keratoplasty; Laser therapy, low-level/ methods; Endothelium corneal; Tomography, optical coherence; Case report

\begin{abstract}
RESUMO
Este relato de caso mostra a confecção de uma lamela corneana doadora endotelial ultrafina com o uso de um laser de femtosegundo de baixa energia e alta taxa de repetição, e sua utilização in vivo em um paciente com ceratopatia bolhosa do pseudofácico. O resultado final foi observado quanto a evolução da espessura da lamela endotelial doadora e de toda a córnea (incluindo mapa paquimétrico), da acuidade visual, e da contagem endotelial ao final de 3 meses de pós-operatório.
\end{abstract}

Descritores: Ceratoplastia endotelial com remoção da lâmina limitante posterior; Terapia a laser de baixa intensidade; Endotélio da córnea; Tomografia de coerência óptica; Relato de caso

\section{INTRODUCTION}

Descemet stripping automated endothelial keratoplasty (DSAEK) is the standard surgical treatment for endothelial failure. Its efficacy is indicated by a spectacle-corrected acuity of 20/40 or better in most patients ${ }^{(1,2)}$. The microkeratome coupled to the artificial chamber can produce an endothelial donor lamella (EDL); however, the cutting irregularities and the unpredictability of the depth of the cut are major impediments to the visual outcome of lamellar transplantation ${ }^{(3,4)}$. New models of femtosecond lasers (FS) produce a better corneal lamella quality than the microkeratome ${ }^{(5-9)}$. Lasers with a high frequency and low energy tend to make a corneal cut smoother, more homogeneous, accurate, and reproducible, as smaller intrastromal bubbles are produced, creating smaller cavities in the cornea ${ }^{(5-9)}$. Cell necrosis and inflammation in the cornea increase as the energy used by FS increases ${ }^{(5-9)}$. There is a direct relationship between the frequency and amount of energy required to form a shooting corneal lamella. With a lower frequency, more energy is required to manufacture the lamella. In addition, with more energy, the size of the intrastromal bubbles and cavities generated by each shot increases, which decreases the laser's precision ${ }^{(5-9)}$. Theoretically, a better visual outcome can be achieved with a thinner and more regular corneal donor lamella produced by a low-energy and high-frequency FS. The objective of this report is to describe, for the first time in Brazil, the creation of an EDL with a low energy and high frequency FS and its subsequent use in vivo.

\section{CASE REPORT}

A 59-year-old female presented with an endothelial failure in the left eye (LE) after phacoemulsification and intraocular lens implantation performed 9 years previously. Figure 1 presents a preoperative photograph of her LE. Her best-corrected visual acuity (BCVA, with glasses) was a finger count at $1 \mathrm{~m}$. The central corneal thickness (CCT) was $730 \mu \mathrm{m}$, as measured by ultrasonic pachymetry (P55, Paradigm ${ }^{\circledR}$, USA). Following the preoperative examinations, she was subjected to DSAEK.

An EDL was prepared with a low energy and high frequency FS $\left(\right.$ LDV $^{\circledR}$, Ziemer $^{\circledR}$ Ophthalmic System AG, Port, Switzerland). This laser operates with a pulse frequency in the megahertz range, with highaperture optics, with a per pulse time exposure of $250 \mathrm{fs}$, and a spot diameter of $2 \mu \mathrm{m}$. The shots were overlapped to avoid leaving untreated areas. The energy per pulse was $30 \mathrm{~nJ}^{(5)}$.

For proper laser application, the donor cornea was first attached to the Ziemer $^{\circledR}$ anterior chamber, the epithelium was removed, and CCT was measured by ultrasonic pachymetry. The donor cornea was then flattened using the head of the laser. The preoperative donor endothelium cell count was 2835 cells $/ \mathrm{mm}^{2}$, and the intraoperative CCT was $590 \mu \mathrm{m}$. The anterior donor lamella was planned to have a 10-mm diameter and a 500- $\mu$ m thickness, theoretically leaving a 90- $\mu \mathrm{m}$ EDL. After laser treatment, the cornea was manually trephined from the endothelial side using an $8-\mathrm{mm}$ trephine blade (Katena ${ }^{\circledR}$ Products, Denville, NJ, USA). Next, the posterior and anterior lamellae
Funding: This study was support by the Foundation for Research Support of the State of São Paulo Funding:
(FAPESP).

Disclosure of potential conflicts of interest: None of the authors have any potential conflicts of interest to disclose.

Corresponding author: Gustavo Victor. Av. República do Líbano, 1.034 - São Paulo (SP) 04002-001 - Brazil - E-mail: gustavo.victor@eyeclinic.com.br 
were separated by holding the edge of the posterior lamella with forceps and gently sliding off the anterior lamella using the tip of a Merocel ${ }^{\circledR}$ sponge (Figure 2).

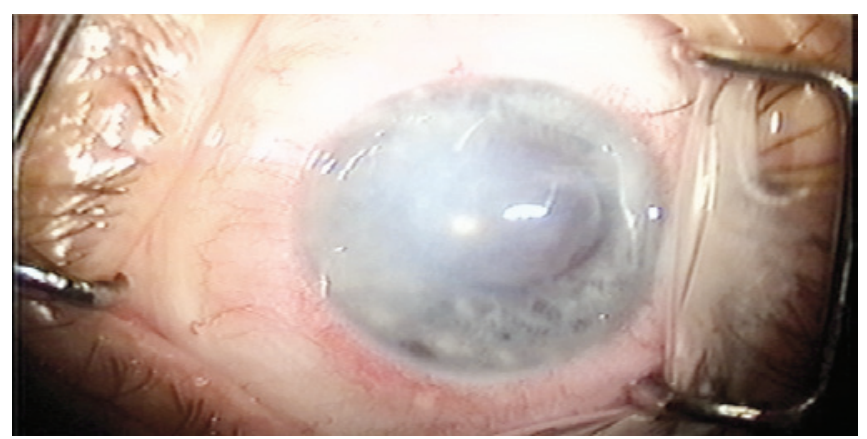

Figure 1. Preoperative photograph of the patient's left eye.

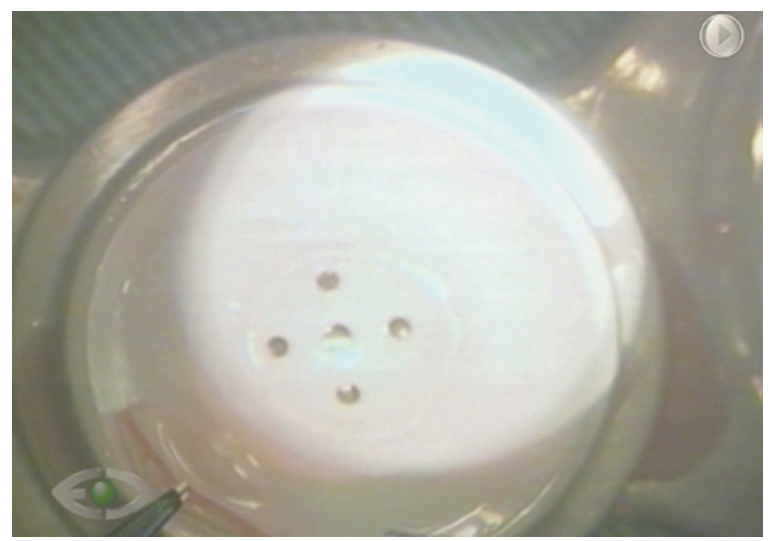

Figure 2. Deep anterior donor cornea lamellae (thicker) being removed. Endothelial donor lamellae (thinner), from same cornea, remains on the bottom with the endothelium side up after cutting with an LDV ${ }^{\circledast}$ femtosecond laser.
The surgeon (WN) performed a standard DSAEK procedure in the receptor eye after peribulbar anesthesia, as described previously ${ }^{(2)}$. In brief, the anterior chamber was filled with air through the paracentesis and a reverse Sinskey hook was used to remove an approximately 8-mm diameter section of the central endothelium and Descemet membrane, previously marked on the host epithelium, through the main 2.4-mm clear corneal incision. Afterwards, the main incision was enlarged with a 5.2-mm surgical blade to insert the endothelial lamella with a Busin ${ }^{\circledR}$ glide (Moria ${ }^{\circledR}$, France). The anterior chamber was maintained with air throughout the procedure. The EDL was positioned over the receptor corneal epithelium using a cannula with smooth movements. The main incision was sutured with a single 10-0 mononylon stitch. The patient remained in the supine position for $2 \mathrm{~h}$ to promote proper EDL adhesion when the air was partially removed and the anterior chamber was filled with balanced saline solution.

After surgery, topical moxifloxacin hydrochloride 0.5\% (Vigamox ${ }^{\circledR}$, Alcon ${ }^{\circledR}$, Brazil) was prescribed four times per day for 1 week and prednisolone acetate $1 \%$ (Predfort ${ }^{\circledR}$, Allergan ${ }^{\circledR}$, Brazil) every $3 \mathrm{~h}$ for 1 week, then six times per day for 1 week, which was decreased thereafter by one application per day each week.

On the first postoperative day, the patient had an uncorrected visual acuity (UCVA) of 20/400 in LE. After 1 month, her BCVA was $20 / 150\left(+1.50-2.50 \times 15^{\circ}\right)$. In the third postoperative month, she had an UCVA of 20/150 and her BCVA improved to 20/30 with a refraction of $+075-2.75 \times 120^{\circ}$. The central and paracentral endothelial lamella thickness was measured with the Visante ${ }^{\circledR}$ OCT (Zeiss ${ }^{\circledR}$, Germany) at $158 \mu \mathrm{m}$ in the first postoperative month and $62 \mu \mathrm{m}$ after the third postoperative month. Figure $3 \mathrm{~A}$ and $3 \mathrm{~B}$ show the Visante ${ }^{\circledR} \mathrm{OCT}$ after 1 month whereas figure $3 \mathrm{C}$ and $3 \mathrm{D}$ show the same after 3 months. Figure 4 presents the global pachymetric map and endothelial cell count in the third postoperative month. Global pachymetric measurements with the Visante ${ }^{\circledR}$ OCT were within the normal range, with $521 \mu \mathrm{m}$ for CCT (Figure 4). The endothelial cell count in the third postoperative month was 1036 cells $/ \mathrm{mm}^{2}$ (Figure 4).

\section{DISCUSSION}

Bullous keratopathy remains one of the leading causes worldwide for corneal transplantation ${ }^{(10)}$. Many surgeons consider DSAEK as the treatment of choice for this condition ${ }^{(1,2)}$. According to the potential

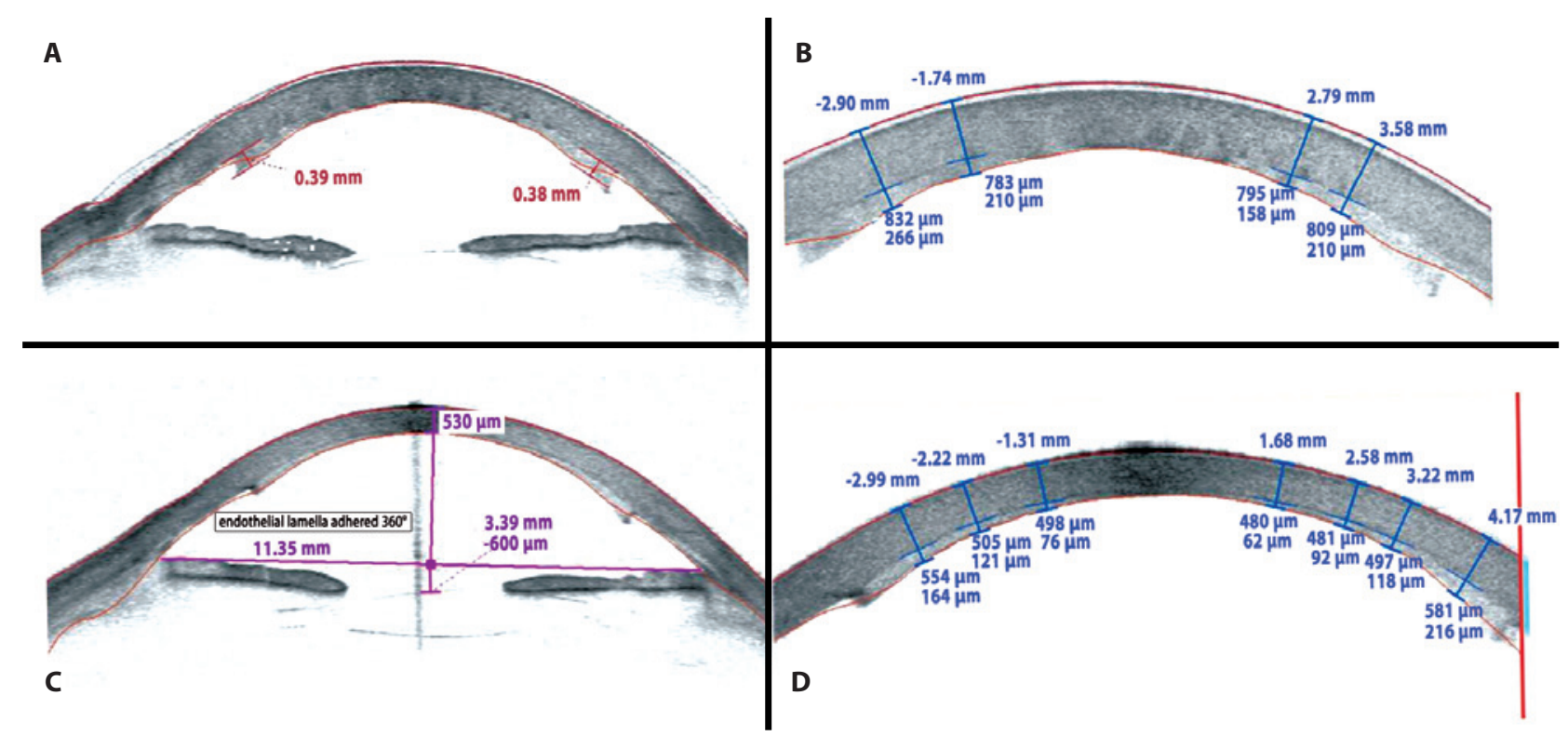

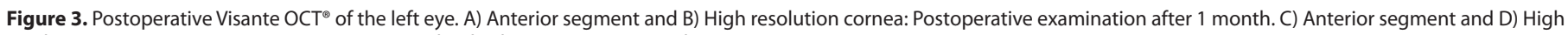
resolution cornea: postoperative examination in the third postoperative month. 


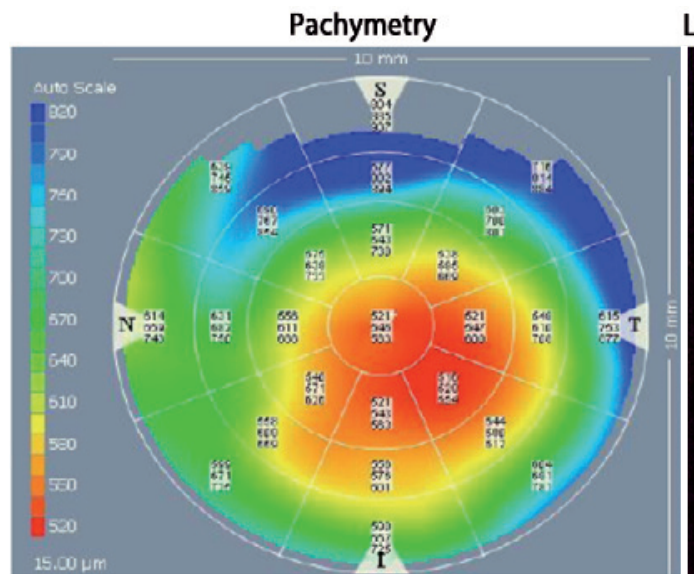

Left eye

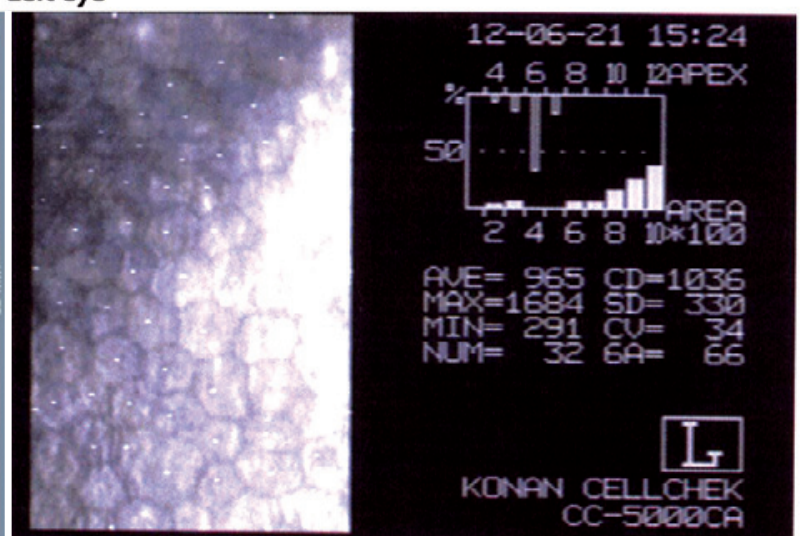

Endothelial cell count: 1036 cells $/ \mathrm{mm}^{2}$

Figure 4. Visante $\mathrm{OCT}^{\circledR}$ global pachymetry map and endothelial cell count in the third postoperative month.

vision of the eye, a thinner EDL will result in a better final visual acuity. The endothelial cell count declined significantly, but could maintain a viable tissue. The EDL was set to $90 \mu \mathrm{m}$ without epithelium, and the effective EDL was $62 \mu \mathrm{m}$. The desired thinner thickness was calculated on the basis of the full thickness of the central cornea after removing it from the Optisol ${ }^{\circledR}$ and placing it in the artificial anterior chamber, which certainly had edema. This shows a certain predictability for this technique using this laser. The primary reasons for this small difference may be the influence of pressure within the artificial anterior chamber at the time of preoperative measurements, pachymetric measure after flattening the cornea with the laser to construct the EDL, and the preoperative corneal edema and laser safety margin. These factors should be considered by the surgeon and examined in future studies. In another in vitro study ${ }^{(9)}$ that used the same FS used in the present study, 5 corneas were cut to produce EDLs with a 70- $\mu \mathrm{m}$ thickness and the mean central posterior stromal thickness of the cut corneas was $60.6 \mu \mathrm{m}$ (range, 43-72 $\mu \mathrm{m}$ ). FS can help spread DSAEK when creating an automated ultrafine EDL and facilitate DSAEK, especially if eye banks can send a pre-cut EDL. The disadvantage is the high cost of FS.

Here, we report the production of an ultrathin EDL using a low energy and high frequency FS. We also report its use in vitro and the outcomes observed 3 months after surgery in terms of the evolution of EDL, the total corneal thickness (including the global pachymetric mapping), the visual acuity, and the endothelial cell count.

\section{REFERENCES}

1. Bahar I, Kaiserman I, McAllum P, Slomovic A, Rootman D. Comparison of posterior lamellar keratoplasty techniques to penetrating keratoplasty. Ophthalmology. 2008; 115(9):1525-33

2. Price MO, Price FW Jr. Descemet's stripping with endothelial keratoplasty: comparative outcomes with microkeratome-dissected and manually dissected donor tissue. Ophthalmology. 2006;113(11):1936-42.

3. Kang PC, McEntire MW, Thompson CJ, Moshirfar M. Preparation of donor lamellar tissue for deep lamellar endothelial keratoplasty using a microkeratome and artificial anterior chamber system: endothelial cell loss and predictability of lamellar thickness. Ophthalmic Surg Lasers Imaging. 2005;36(5):381-5.

4. Thiel MA, Kaufmann C, Dedes W, Bochmann F, Becht CN, Schipper I. Predictability of microkeratome-dependent flap thickness for DSAEK. Klin Monbl Augenheilkd. 2009; 226(4):230-3.

5. Lubatschowski H. Overview of commercially available Femtosecond lasers in refractive surgery. J Refract Surg. 2008;24(1):S102-107.

6. Salomão MQ, Wilson SE. Femtosecond laser in laser in situ keratomileusis. J Cataract Refract Surg. 2010;36(6):1024-32.

7. Ahn H, Kim JK, Kim CK, Han GH, Seo KY, Kim EK, et al. Comparison of laser in situ keratomileusis flaps created by 3 femtosecond lasers and a microkeratome. J Cataract Refract Surg. 2011;37(2):349-57.

8. Medeiros FW, Kaur H, Agrawal V, Chaurasia SS, Hammel J, Dupps WJ Jr, et al. Effect of femtosecond laser energy level on corneal stromal cell death and inflammation. J Refract Surg. 2009;25(10):869-74.

9. Phillips PM, Phillips LJ, Saad HA, Terry MA, Stolz DB, Stoeger C, et al. "Ultrathin” DSAEK tissue prepared with a low-pulse energy, high-frequency femtosecond laser. Cornea. 2013;32(1):81-6.

10. Zhang C, Xu J. Indications for penetrating keratoplasty in East China, 1994-2003. Graefes Arch Clin Exp Ophthalmol. 2005;243(10):1005-9. 